ELORE (ISSN 1456-3010), vol. $18-2 / 2011$.

Julkaisija: Suomen Kansantietouden Tutkijain Seura ry.

[http://www.elore.fi/arkisto/2_11/leinonen.pdf]

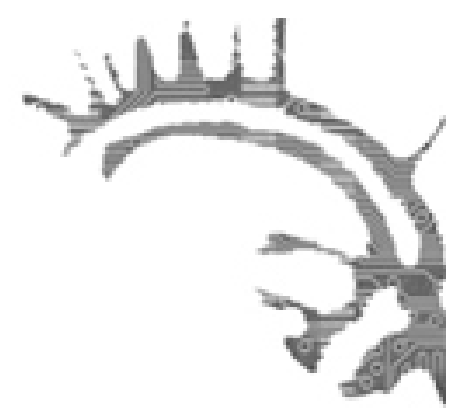

KIRJA-ARVIO

\title{
TALLITYTTÖJEN MAAILMA
}

OJANEN, KAROLIINA 2011: Tyttöjen toinen koti - Etnografinen tutkimus tyttökulttuurista ratsastustalleilla. Helsinki: SKS. 325 sivua.

\section{Riitta-Marja Leinonen}

Karoliina Ojanen laajentaa folkloristiikan väitöstutkimuksessaan tyttötutkimusta tärkeään suuntaan, nimittäin tallityttöihin. Tallilla käyminen on tärkeä osa monen suomalaisen tytön elämää ja tallityttöjen tutkiminen antaa hyvän näköalan tyttöyden luomiseen ja käytäntöihin. Lisäksi tallitytöt muodostavat kulttuurissamme harvinaisia tyttöjen dominoimia yhteisöjä. Ojanen tutkii sitä, miten tytöt luovat tyttöyttään ratsastustallin yhteisössä, minkälaista tyttökulttuuri on ratsastustallilla ja millaisia kulttuurisia sukupuolikäsityksiä tytöt muodostavat. Tallityttökulttuuri on pohjoismainen ilmiö, joka liittyy pohjoismaiseen vahvaan naisen asemaan. Tytöt myös sosiaalistetaan hevosharrastukseen jo pienestä pitäen. Tämä käy ilmi vilkaisemalla lasten lelukuvastoja, tytöille suunnattuja lehtiä, kirjoja tai internetin keskustelufoorumeita.

Tallitytöillä Ojanen tarkoittaa tyttöjä, jotka hoitavat ilmaiseksi muiden omistamia hevosia. Tallityttöjen tehtäviin kuuluvat hevosten harjaaminen, ruokinta, varusteiden huolto, karsinoiden puhdistus ja hevosten talutus esimerkiksi aloittelijoiden ratsastustunnilla. Tytöt käyvät tallilla useana iltana viikossa ja he viettävät siellä useita tunteja kerrallaan.

\section{FEMINISTISEN ETNOGRAFIAN NÄKÖKULMA TALLITYTTÖYTEEN}

Ojanen käyttää tutkimusmenetelmänä feminististä etnografiaa, joka tiedostaa tutkijan valintojen poliittisuuden ja sen, että tyttöjen ääni kuuluu vain tutkijan tulkintojen kautta. Feministiseen tutkimusotteeseen kuuluu myös avoin refleksiivisyys, jossa 
Ojanen - itsekin entinen tallityttö - on onnistunut hyvin. Hän kertoo häpeän ja pelon tunteista kentällä erityisesti kenttätyön alkuvaiheessa ja on onnistunut sopivasti etäännyttämän itsensä tallityttöydestään sekä analysoimaan kentän reaktioita. Ojanen on kerännyt materiaalinsa haastattelemalla ja havainnoimalla tyttöjä kolmella tallilla. Tutkimusmateriaalina hänellä on 22 tallitytön haastattelut ja kenttätyöpäiväkirja, johon hän on dokumentoinut havaintonsa. Ojasen etnografiassa tytöt ovat asiantuntijoita, ja heidän äänensä kuuluu haastattelusitaateissa, joita Ojanen on käyttänyt paljon työssään. Sitaattien autenttisuus tuskin olisi kärsinyt, jos niistä olisi luettavuuden nimissä poistettu toistoa ja muutamia niinku-sanoja.

Ojanen yhdistää tallityttöyden tarkastelussa onnistuneesti kaksi teoreettista tarkastelutapaa, antropologisen folkloristiikan perinne-käsityksen ja performatiivisen sukupuolen käsityksen. Antropologisessa folkloristiikassa perinne nähdään ryhmien ominaisuutena, jolla on merkitystä ryhmän identiteetille ja jatkuvuudelle. Tutkimuksessaan Ojanen viittaa perinteen käsitteellä tallityttöjen tapoihin ja tallilla käymisen merkityksiin. Performatiivisella sukupuolella hän viittaa Judith Butlerin teoriaan, jonka mukaan sukupuoli on ensisijaisesti tekemistä. Ojanen tarkastelee näiden käsitteiden avulla, miten sukupuoli voi olla perinnettä. Sukupuoliperinteellä hän tarkoittaa haastattelupuheessa muotoutuvia jaettuja käsityksiä tallityttöydestä. Esimerkiksi hoivavietistä puhuminen osoittaa tyttöjen tuntevan sukupuoliperinteen stereotypioita, mutta he varioivat näitä tyypittelyjä yksilötasolla.

\section{TYTTÖJEN JA HEVOSTEN SUHTEESTA}

Ojanen perustaa ihmisen ja hevosen suhteen tarkastelun Donna Harawayn ja Karen Baradin ruumisteoreettisille näkemyksille, joiden mukaan eläimet osallistuvat tekemisillään siihen, mitä me näemme ja minkälaista tietoa tuotamme. Jokainen hevosten kanssa tekemisissä ollut tietää, ettei hevosten ruumiillisuuden merkitystä voi sivuuttaa. Kun vastapuolena on pieni tyttö, asetelma on vähintäänkin mielenkiintoinen. Mieleen nouseekin kysymys, miten tytöt pystyvät hallitsemaan suuria hevosia?

Tallitytöt tietävät salaisuuden hevosten kanssa toimimiseen: niitä ei saa pelätä. Hevosen käsittely ja hoitaminen on kovaa työtä ja se vaatii rohkeutta. Hoitaminen ei näyttäydy tallityttökulttuurissa vain hoivaamistarpeena ja tunnepitoisena elämyksenä, vaan se tarkoittaa kykyä lukea suuren pakoeläimen käyttäytymistä ja eläimen käsittelytaitoa silloinkin, kun eläin on ahdistunut tai peloissaan. Hoitamiseen liittyy vallan käyttöä. Tytön ja hevosen suhde ei ole tasavertainen, vaan siinä valta on tytöllä. Suhteeseen liittyy myös väkivaltaa, joka on tyttöjen mukaan joskus tarpeellista hevosen hallitsemiseksi.

Tallityttöjen suhteet hoitohevosiin kestävät muutamista kuukausista vuosiin ja tytöt luovat voimakkaita kiintymyssuhteita hevosiin. Suhde hoitohevoseen kuvataan luottamukselliseksi kumppanuudeksi. Ojanen kertoo, kuinka isokokoinen hevonen auttoi pienikokoista hoitajaansa suoriutumaan hoitotehtävistään laskemalla päänsä alas suitsien laittoa varten ja nojautumalla alemmaksi, jotta tyttö ylsi harjaamaan sen 
selän. Läheisen suhteen saavuttaminen hevosen kanssa on sekä psykologisesti tärkeää tytölle itselleen että yhteisöllisesti arvostettua. Eläimen osoittama hyväksyntä ja luottamus sekä se, että tytöt voivat purkaa eläimelle tuntojaan, luovat yhteyden tunteen tytön ja hevosen välille.

Hevoset ovat aktiivisia toimijoita tallityttöjen puheessa. Ne osallistuvat tallikulttuurin tuottamiseen, joskaan eivät intentionaalisesti. Hevosten ominaisuudet, käytös ja koko ohjaavat tyttöjen toimintaa, käsityksiä ja normeja. Pidän erityisesti siitä, miten Ojanen tarkastelee hevosen merkitystä aktiivisena toimijana tallityttökulttuurin tuottamisessa ja haastaa tätä kautta käsitystä kulttuurista vain ihmisten keskenään tuottamana.

\section{HEVOSTEN YMPÄRILLE JÄRJESTÄYTYVÄ TYTTÖJEN YHTEISÖ}

Tytöt eivät käy tallilla vain ratsastamassa, vaan talli on heille yhteinen sosiaalinen tila. Tytöt ovat tallilla tuntikausia päivässä, mutta aikaa ei käytetä kokonaan hevosten hoitamiseen. Suurin osa tallilla vietetystä ajasta kuluu toisten tyttöjen kanssa keskustellessa ja tallityttöyhteisössä toimiessa. Ojanen on kiinnostunut siitä, miten tyttöyhteisön rakenne muodostuu ja millainen sen järjestys on. Tallitytöt muodostavat tiukan hierarkkisen yhteisön, jossa tytöt toimivat laajemmissa porukoissa, eivätkä pareittain kuten tavallisesti oletetaan. Tytöt käyttävät avoimesti valtaa niin toisiin tyttöihin kuin hevosiinkin. Tyttöjen välinen hierarkia rakentuu tytön iän, hoitohevosen, tehtävien ja tilan käytön mukaan. Hoitohevosen ominaisuuksista tyttöjen hierarkiaan vaikuttava seikka on hevosen omistaja, sillä yksityisomistuksessa olevan hevosen hoitaja on korkeammalla tyttöjen arvoasteikossa kuin ratsastuskoulun hevosen hoitaja. Tehtävät tallilla tulevat puolestaan sitä vaativammiksi mitä kokeneempi tyttö on. Ratsastuskoulun tilat jakautuvat yleensä yksityisten hevosten ja ratsastuskoulun puoleen. Yksityisten hevosten puolelle ei ole kaikilla pääsyä ratsastuskoulun puolen ollessa kaikille avoin.

Pojilla ei ole pääsyä tähän yhteisöön. Heidät saatetaan torjua tylystikin tallilla, sillä tyttöjen mielestä yhteisö ja tyttöjen käyttäytyminen muuttuisi poikien myötä. Tytöt alkaisivat poikien takia kiinnittää enemmän huomiota ulkonäköönsä, jota ei tallilla ole tapana korostaa. Lisäksi pojilla koetaan olevan jo niin paljon harrastusmahdollisuuksia, että tytöt haluavat pitää tallin omana tilanaan. Tytöt ajattelevat poikien myös olevan niin vallanhaluisia ja kilpailuvietin ajamia, että he eivät pystyisi hevosen kanssa tarvittavaan vastavuoroisuuteen. Myös tytöt kilpailevat ratsastuksessa, mutta he mieltävät oman kilpailuviettinsä erilaiseksi kuin poikien tai miesten kilpailuhalun. Muutenkin tytöt mieltävät miesten hevosiin kohdistaman väkivallan aggressiivisemmaksi kuin heidän itsensä käyttämän. Miehet näkyvät tutkimuksen kohteena olevilla ratsutalleilla lähinnä karnevalisoituina ryhminä, esimerkiksi työ- tai polttariporukoina. Tyttöjen näkökulmasta nämä hevosiin tottumattomat miehet vaikuttavat reppanoilta, jotka eivät voi muuta kuin noudattaa tyttöjen käskyjä.

Talli tarjoaa tytöille paikan, jossa he voivat saavuttaa sosiaalisen toiminnan, taitavuuden ja hallitsemisen kokemuksia, joihin heillä ei muualla ole mahdollisuutta. Eroottisuuden sulkeminen yhteisön ulkopuolelle voidaan nähdä tyttöjen kommenttina 


\section{Riitta-Marja Leinonen: Tallityttöjen maailma}

valtakulttuurille, jonka mukaan tyttöjen pitäisi näyttää seksikkäiltä ja haluttavilta. Toisaalta heidän toimintansa vahvistaa heteronormatiivista käsitystä siitä, että seksikkyys kuuluu ympäristöön, jossa on myös poikia ja miehiä. Yhteiskuntaluokalla ei tallityttöjen keskuudessa ole väliä. Tyttöjen lähtökohdat saattavat olla hyvinkin erilaisia, mutta he toimivat tallilla yhdessä. Ristiriitoja yhteisössä aiheuttavat kiistat hoitohevosista, sillä samalla hevosella voi olla useampi hoitaja. Vaikka tytöt korostavat harmoniaa ja ystävällisyyttä, talleilla ilmenee kuitenkin juoruilua, selän takana haukkumista ja toisia syrjivää liittoutumista.

Ratsastuskoulun talli on julkisena tilana avoimena koko päivän ja se mahdollistaa tyttöjen yhteisen ja vapaan ajanvieton toisin kuin monessa muussa harrastuksessa. Toiminta ei ole tallilla myöskään yhtä ohjattua kuin esimerkiksi tanssin harrastaminen. Yksi avainkokemus tallilla on hyväksyntä, jota tytöt saavat sekä ihmisiltä että eläimiltä. Tämän lisäksi tytöt saavat tallilta turvallisuuden, yhteenkuuluvuuden, osaamisen, itsensä kehittämisen ja jatkuvuuden tunteita.

\section{IHANTEELLINEN TALLITYTTÖ}

Ojanen selvittää myös tallityttöyhteisön normeja. Hoitajaihanteeseen kuuluu hiljaisuus, itsensä korostamisen välttäminen, reippaus, työlle omistautuminen, sitkeys ja pelottomuus. Nämä määreet muistuttavat perinteistä "hyvä tyttö'-stereotypiaa ja agraarisen naisen mallia. Käyttäytymisnormeja tytöt perustelevat tallimiljööllä ja hevosten läsnäololla. Esimerkiksi tupakanpoltto on tallissa kiellettyä eikä tupakoivia tyttöjä käynyt tutkimuksen kohteina olevilla talleilla ollenkaan. Selityksenä tupakoimattomuudelle nähtiin se, että hevosten olisi vaikea hengittää savuista ilmaa ja tupakointi saattaisi johtaa koko tallin tuhoutumiseen.

Tyttöjen mukaan tallilla käyminen pitää heidät poissa huonoista elämäntavoista, eikä vanhempien tarvinnut olla tytöistä huolissaan. Harrastusta kuvataan "pelastukseksi”, joka estää murrosikäisten tyttöjen ajautumisen huonoon seuraan, ryyppäämään ja teiniäideiksi. Tytöt kuvaavat tallilla käyntiä jopa terapeuttiseksi, sillä se työntää ikävät asiat ja murrosiän myrskyt taka-alalle.

Ojanen purkaa hienosti tyttöjen vaatetusta koskevaa normistoa ja kulttuurisia merkityksiä. Tyttöjen tallipukeutuminen eroaa työn luonteeseen kuuluvan lian ja hajun vuoksi muualla käytetystä vaatetuksesta. Liian hyvin ei tallille sovi pukeutua ja hame on pukineena vastoin kaikkia yhteisön normeja. Yhteisön pukeutumiseen liittyvään normistoon sitoutuminen antaa tytöille mahdollisuuden vapautua muualla vallitsevista valtakulttuurin luomista ulkonäköpaineista. Tallilla vaatteiden likaisuus ja haiseminen eivät ole ristiriidassa tyttöyden kanssa. Tässä tytöt eivät Ojasen mukaan liiku maskuliinisuuden ja feminiinisyyden välimaastossa, vaan tuottavat omantyylistä tyttöyttä. Hevosen hoidon ympärille rakentuvassa yhteisössä tytöt kokevat saavansa enemmän tilaa kuin muualla. Hierarkiassa ylempänä olevat tytöt käyttävät ääntään, juoksevat ja riehuvat tallissa, vaikka se on hoitajaihanteen vastaista käytöstä. Hierarkiassa eteneminen vaatii määrätietoisuutta ja vallan käyttöä, mikä ei näy tallitytön ideaalikuvassa. 


\section{LOPUKSI}

Ojasen väitöskirja on mielenkiintoista luettavaa myös muille kuin folkloristeille. Tutkimuksesta löytyy raikasta näkökulmaa erityisesti nais- ja tyttötutkimukseen, mutta Ojanen käsittelee ansiokkaasti myös ihmisen ja hevosen suhdetta. Työ on helppolukuinen sisältäen kuitenkin reilusti teoreettista analyysiä etnografisen kerronnan lomassa. Asioiden toistoa on jonkin verran, mutta tätä on pidettävä pienenä pahana, sillä kirja kokonaisuudessaan on nautittavaa luettavaa. Arvostan erityisesti sitä, miten Ojanen analysoi ja purkaa tallityttöyteen ja ratsastukseen liitettyjä stereotypioita kuten hoitamista pelkkänä ponien halailuna tai vain tiettyyn elämänvaiheeseen liittyvää harrastusta, jonka seurustelusuhde pojan kanssa keskeyttää. Ojanen osoittaa, miten tytöt kykenevät nielemään pelkonsa ja käsittelevät suuria eläimiä, mutta saavat tallin ulkopuolella pojilta osakseen lähinnä pilkkaa. Todellisuus tallilla toimimisesta on kovin erilainen kuin mitä sitä tuntematon yleensä olettaa.

Filosofian maisteri Riitta-Marja Leinonen valmistelee väitöskirjaa kulttuuriantropologian oppiaineeseen Oulun yliopistossa ihmisen ja hevosen suhteesta ja suomalaisen hevoskulttuurin muutoksesta. 